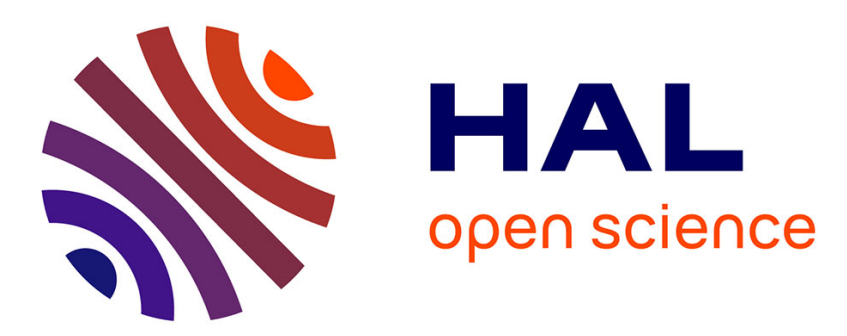

\title{
Iodate and iodo-trihalomethane formation during chlorination of iodide-containing waters: Role of bromide
}

Justine Criquet, Sebastien Allard, Elisabeth Salhi, Cynthia Joll, Anna Heitz, Urs von Gunten

\section{To cite this version:}

Justine Criquet, Sebastien Allard, Elisabeth Salhi, Cynthia Joll, Anna Heitz, et al.. Iodate and iodotrihalomethane formation during chlorination of iodide-containing waters: Role of bromide. Environmental Science and Technology, 2012, 46 (13), pp.7350-7357. 10.1021/es301301g • hal-02592865

\section{HAL Id: hal-02592865 \\ https://hal.science/hal-02592865}

Submitted on 15 May 2020

HAL is a multi-disciplinary open access archive for the deposit and dissemination of scientific research documents, whether they are published or not. The documents may come from teaching and research institutions in France or abroad, or from public or private research centers.
L'archive ouverte pluridisciplinaire HAL, est destinée au dépôt et à la diffusion de documents scientifiques de niveau recherche, publiés ou non, émanant des établissements d'enseignement et de recherche français ou étrangers, des laboratoires publics ou privés. 


\section{Iodate and iodo-trihalomethane formation during chlorination of iodide-containing waters: Role of bromide.}

\begin{tabular}{|r|l|}
\hline Journal: & Environmental Science \& Technology \\
\hline Manuscript ID: & es-2012-01301g.R1 \\
\hline Manuscript Type: & Article \\
\hline Date Submitted by the Author: & n/a \\
\hline Complete List of Authors: & $\begin{array}{l}\text { Criquet, Justine; EAWAG, Swiss Federal Institute of Aquatic Science and } \\
\text { Technology, ; Curtin University of Technology, Curtin Water Quality } \\
\text { Research Centre } \\
\text { Allard, Sebastien; Curtin University of Technology, Curtin Water Quality } \\
\text { Research Centre } \\
\text { Salhi, Elisabeth; EAWAG, Swiss Federal Institute of Aquatic Science and } \\
\text { Technology, } \\
\text { Joll, Cynthia; Curtin Water Quality Research Centre, Department of Applied } \\
\text { Chemistry } \\
\text { Heitz, Anna; Curtin University of Technology, Applied Chemistry } \\
\text { von Gunten, Urs; EAWAG, Swiss Federal Institute of Aquatic Science and } \\
\text { Technology, WUT; Ecole Polytechnique Fédérale de Lausanne (EPFL), } \\
\text { School of Architecture, Civil and Environmental Engineering (ENAC) }\end{array}$ \\
\hline
\end{tabular}

\section{SCHOLARONE ${ }^{\text {Tw }}$}

Manuscripts 
lodate and iodo-trihalomethane formation during chlorination of iodide-containing 2 waters: Role of bromide.

3

Justine Criquet $^{\mathrm{a}, \mathrm{b}}$, Sebastien Allard ${ }^{\mathrm{b}}$, Elisabeth Salhi ${ }^{\mathrm{a}}$, Cynthia A. JolI ${ }^{\mathrm{b}}$, Anna Heitz ${ }^{\mathrm{b}}$ and Urs von Gunten ${ }^{\mathrm{a}, \mathrm{c}, \mathrm{d} *}$.

* corresponding author: urs.vongunten@eawag.ch

a. Eawag, Swiss Federal Institute of Aquatic Science and Technology, $\mathrm{CH}-8600$, Dübendorf, Switzerland.

b. Curtin Water Quality Research Centre, Curtin University, G.P.O. Box U1987, Perth, WA 6845, Australia.

c. School of Architecture, Civil and Environmental Engineering (ENAC), Ecole Polytechnique Fédérale de Lausanne (EPFL), CH-1015 Lausanne, Switzerland.

d. Institute of Biogeochemistry and Pollutant Dynamics, ETH Zentrum, CH-8092 Zürich, Switzerland.

Abstract

The kinetics of iodate formation is a critical factor in mitigation of the formation of potentially toxic and off flavour causing iodoorganic compounds during chlorination. This study demonstrates that the formation of bromine through the oxidation of bromide by chlorine significantly enhances the oxidation of iodide to iodate in a bromide-catalysed process. The $\mathrm{pH}$-dependent kinetics revealed species specific rate constants of $k\left(\mathrm{HOBr}+1 \mathrm{O}^{-}\right)=1.9 \times 10^{6} \mathrm{M}^{-}$ ${ }^{1} \mathrm{~s}^{-1}, k\left(\mathrm{BrO}^{-}+\mathrm{IO}^{-}\right)=1.8 \times 10^{3} \mathrm{M}^{-1} \mathrm{~s}^{-1}$ and $\mathrm{k}(\mathrm{HOBr}+\mathrm{HOI})<1 \mathrm{M}^{-1} \mathrm{~s}^{-1}$. The kinetics and the yield of iodate formation in natural waters depend mainly on the naturally occurring bromide and the relative I-incorporation in I-THMs decreased from 18 to $2 \%$ when the free chlorine contact time was increased from 2 to 20 minutes (chlorine dose $1 \mathrm{mg} \mathrm{Cl}_{2} / \mathrm{L}$ ). This observation is inversely correlated with the conversion of iodide to iodate, which increased from 10 to nearly $90 \%$.

34 Increasing bromide concentration also increased the conversion of iodide to iodate: from 45 to 
nearly $90 \%$ with a bromide concentration of 40 and $200 \mu \mathrm{g} / \mathrm{L}$, respectively and a prechlorination time of $20 \mathrm{~min}$, while the I-incorporation in I-THMs decreased from 10 to $2 \%$.

\section{Introduction:}

lodide in source waters is rapidly oxidized to hypoiodous acid during oxidation and disinfection with chlorine, monochloramine and ozone..$^{1-4}$ During oxidative water treatment, hypoiodous acid $(\mathrm{HOI})$ is formed and can be further oxidized to iodate $\left(\mathrm{IO}_{3}^{-}\right)$or react with $\mathrm{NOM}$ to form iodo-organic compounds as disinfection by-products (DBPs). ${ }^{5,6}$ It has been shown that iodotrihalomethanes (I-THMs) are more toxic than their brominated and chlorinated analogues and iodoacetic acid has been found to be the most genotoxic DBP identified to date. ${ }^{7,8}$ Moreover, ITHMs, especially iodoform, were associated with a characteristic medicinal taste and odor which may appear in finished drinking water. ${ }^{9}$ In fact, these compounds have low odor threshold concentrations ranging from 0.03 to $8.9 \mu \mathrm{g} / \mathrm{L}$, with the lowest concentration being for iodoform. ${ }^{10}$ The occurrence of I-THMs and iodo-acids has been studied and these compounds were found in most finished drinking waters when the iodide levels in the corresponding source waters were between 0.4 and more than $100 \mu \mathrm{g} / \mathrm{L} .{ }^{8}$ The formation of iodoorganic compounds is favored in waters containing a high iodide concentration and, among existing disinfection processes, it was shown that chloramination leads to the highest concentrations of iodoDBPs. ${ }^{5,8,9,11,12}$ In a survey of the occurrence of DBPs in the United States, the highest I-THM concentration was observed for a simultaneous addition of chlorine and ammonia. ${ }^{11}$ Another survey showed the relationship between the formation of I-THMs and the free chlorine contact time, with shorter contact times inducing a higher formation of I-THMs. ${ }^{8}$ These observations are related to the further oxidation of $\mathrm{HOI}$, the first oxidation product of $\mathrm{I}^{-}$, which determines the fate of iodine compounds in oxidative treatment. Only ozone and chlorine oxidize $\mathrm{HOI}$ and IOto $\mathrm{IO}_{3}{ }^{-}$, iodate formation does not occur with monochloramine. lodate is the desired sink of iodide in drinking water treatment. In contrast to bromate, iodate has been conferred a "Generally Recognized as Safe" status by the United States Food and Drug Administration. ${ }^{13}$ 
63

64

65

66

67

68

69

70

71

72

73

74

75

76

77

78

79

80

81

82

83

84

85

86

87

88

89

Chlorine species oxidize $\mathrm{HOI}$ by a combination of second- and third-order reactions $(k \prime)(\mathrm{HOCl}+$ $\mathrm{HOI})=8.2 \mathrm{M}^{-1} \mathrm{~s}^{-1} ; k^{\prime \prime \prime}(\mathrm{HOCl}+\mathrm{HOCl}+\mathrm{HOI})=8.3 \times 10^{4} \mathrm{M}^{-2} \mathrm{~s}^{-1}$ and $\left.k^{\prime \prime}\left(\mathrm{ClO}^{-}+\mathrm{HOI}\right)=52 \mathrm{M}^{-1} \mathrm{~s}^{-1}\right){ }^{4}$ It has been shown that an increasing chlorine dose caused a reduced level of iodinated organic by-products due to the formation of iodate. ${ }^{6}$ However, the kinetics of the formation of iodate by chlorine is quite slow (half-life of iodide around $40 \mathrm{~min}$ for a chlorine concentration of $1 \mathrm{mg} / \mathrm{L})$ and on this basis it is difficult to explain these observations. Usually natural waters containing high concentrations of iodide also contain elevated concentrations of bromide. ${ }^{8}$ During chlorination, bromide is oxidized to $\mathrm{HOBr}$ (Table 2, Eq. 19). ${ }^{14}$ Bromine has generally a higher reactivity than chlorine. For example, the reaction rate of bromine with phenolic compounds has been found to be $10^{3}$ times higher than that for chlorine. ${ }^{15-18}$ Several studies considering the effect of the presence of bromide during chlorination focus only on the differences in the extent of formation of halogenated compounds. ${ }^{6,19-22}$

In this study we investigate the influence of bromide on the kinetics of iodate formation during chlorination of iodide-containing natural and synthetic waters. Furthermore, the effect of DOM type and concentration on iodate formation was studied. Finally, the effect of the bromide concentration on the mitigation process for iodo-organic compounds, based on free chlorine followed by ammonia addition was investigated in natural waters.

\section{Materials and Methods}

Chemicals. All reagents used were of the highest purity. $\mathrm{HOBr}$ was produced through the oxidation of $\mathrm{Br}^{-}$by $\mathrm{HOCl}$ from a $\mathrm{NaOCl}$ stock solution (Sigma Aldrich) of $1.29 \mathrm{M}$ (determined by iodometry $\left.{ }^{23}\right) . \mathrm{Br}^{-}$was added in a slight stoichiometric excess of $1.05 \times[\mathrm{HOCl}]$. The concentration of the $\mathrm{HOBr}$ stock solution $\left(7 \times 10^{-2} \mathrm{M}\right)$ was determined by photometry $\left(\varepsilon_{329 \mathrm{~nm}}\left(\mathrm{BrO}^{-}\right)=332 \mathrm{M}^{-1} \mathrm{~cm}^{-1}\right.$; after adjusting the $\mathrm{pH}$ of the solution to 11$) .{ }^{15}$ Experiments were performed in ultra-pure water (Barnstead Nanopure (Skan); TOC $<0.2 \mathrm{mg} / \mathrm{L} ; 18.2 \mathrm{~m} \Omega \mathrm{cm}$ ). $\mathrm{pH}$ was controlled by $5 \mathrm{mM}$ phosphate, borate or carbonate buffers. 
90 Natural waters. Five natural waters were collected in Switzerland and in Western Australia.

91 Their key water quality characteristics are summarized in Table 1. The collected waters were 92 filtered through $0.45 \mu \mathrm{m}$ membranes before storage at $4{ }^{\circ} \mathrm{C}$. To allow a comparison of iodate 93 formation for the different waters, they were diluted to obtain the same DOC concentration (1.2 $94 \mathrm{mg} \mathrm{C/L}$ ) and then spiked in order to achieve the same final concentration of iodide (50 $\mu \mathrm{g} / \mathrm{L}$; $950.4 \mu \mathrm{M})$ and bromide $(100 \mu \mathrm{g} / \mathrm{L} ; 1.25 \mu \mathrm{M})$. The $\mathrm{pH}$ was adjusted to 8.0 and, for the waters from 96 Great Southern River, North West Reservoir and Great Southern Reservoir, in which 97 deviations of $\mathrm{pH}$ during chlorination occurred, a phosphate buffer ( $5 \mathrm{mM})$ was added.

99 Table 1

100

Ions and trihalomethane analysis. $\mathrm{Br}^{-}$and $\mathrm{IO}_{3}{ }^{-}$analysis were performed in both laboratories by ion chromatography (Dionex ICS 3000) on an AG-S9 column. Low quantification limits for iodate were obtained by a post-column reaction with UV/Vis detection of $I_{3}{ }^{-}$at $288 \mathrm{~nm}^{24}$ The quantification limits were 10 and $1 \mu \mathrm{g} / \mathrm{L}$ for $\mathrm{Br}^{-}$and $\mathrm{IO}_{3}{ }^{-}$, respectively. lodide was determined by an ion-selective electrode (Orion 96-53 Combination iodide electrode) for the Swiss waters and by ion chromatography for the Australian waters, with a quantification limit of $10 \mu \mathrm{g} / \mathrm{L}$. Most of 107 the iodate samples were analysed at least twice, an average of the values was determined, the standard deviation of the method was around $5 \%$.

109 Trihalomethanes (I-THMs and THM4) were analyzed by a headspace solid-phase 110 microextraction-gas chromatography-mass spectrometry (SPME-GC-MS). ${ }^{25}$ The error bars 111 (Figure 5 and S7-9) represent the values obtained by a repetition of the analysis on each 112 sample. More detailed information for each compound (detection, quantification limits and reproducibility) can be found in a previous publication. ${ }^{25}$

115 Chlorination/bromination experiments. Experiments were performed at $24 \pm 1{ }^{\circ} \mathrm{C}$ in a 500 $116 \mathrm{~mL}$ batch reactor equipped with a dispenser. The oxidant concentration was measured using 117 the colorimetric method based on diethyl-p-phenylene diamine (DPD). ${ }^{23}$ Small volumes of 
1

2
118 sodium hypochlorite or hypobromite stock solutions were added at $t=0$ to the different water

119 samples and aliquots of reaction solutions were withdrawn after $15 \mathrm{~s}-5 \mathrm{~h}$ and added to an 120 excess $(20 \times)$ of sodium sulfite solution to quench the oxidants before iodate analysis. Aliquots were also added to a DPD/phosphate buffer mixture to determine residual oxidant concentrations. To determine the rate constants for the reaction of $\mathrm{HOBr}$ with $\mathrm{HOI}$, triplicate experiments were performed under pseudo first order conditions by measuring the formation of iodate in the presence of an excess of bromine $\left(\left[\mathrm{HOBr} / \mathrm{BrO}^{-}\right]=2 \mu \mathrm{M}\right.$ and $\left.\left[^{-}\right]=0.1 \mu \mathrm{M}\right)$, the $\mathrm{pH}$ range was 5.4 to 11.5 .

\section{Chlorine-ammonia experiments for trihalomethane mitigation}

The natural water was diluted and spiked with aliquots of stock solutions of iodide and bromide to achieve a dissolved organic carbon (DOC) concentration of $1.2 \mathrm{mg} \mathrm{C} / \mathrm{L}$ and desired concentrations of $50 \mu \mathrm{g} / \mathrm{L}$ and from 40 to $200 \mu \mathrm{g} / \mathrm{L}$, respectively for $\mathrm{I}^{-}$and $\mathrm{Br}^{-}$. The reactions were initiated in $100 \mathrm{~mL}$ batch reactors by the addition of chlorine to yield $1 \mathrm{mg} / \mathrm{L}$ as $\mathrm{Cl}_{2}$. At different reaction times $(0,2,5,10,20 \mathrm{~min})$, an aliquot of ammonium chloride solution $(10 \times$ molar excess compared to the initial chlorine concentration) was added to quench the residual chlorine by the formation of monochloramine. After 24 hours, samples were withdrawn for iodate and trihalomethane measurements. The iodate concentrations measured after the different reaction time by quenching with sulfite and after 24 hours after addition of $\mathrm{NH}_{4} \mathrm{Cl}$ were identical. Experiments without addition of $\mathrm{NH}_{4} \mathrm{Cl}$ (i.e. $24 \mathrm{~h}$ chlorination) were also performed for comparison. 


\section{Results and Discussion}

139

\section{Effect of bromide on the kinetics of iodate formation during chlorination}

141 The oxidation of iodide by chlorine has been studied previously. ${ }^{2}$ The first step is the oxidation

142 of $\mathrm{I}^{-}$to $\mathrm{HOI}$ and is very fast. ${ }^{3}$ This reaction occurs immediately, then 2 additional moles of $\mathrm{HOCl}$

143 per mole of $\mathrm{HOI}$ are consumed to yield $\mathrm{IO}_{3}{ }^{-}$. Figure 1 shows the effect of bromide on iodate

144 formation, chlorination experiments were performed in the presence of various concentrations

145 of bromide (i.e. ultrapure water; $\left[\mathrm{I}^{-}\right]_{0}=1 \mu \mathrm{M}(127 \mu \mathrm{g} / \mathrm{L})$; $[\mathrm{HOCl}]_{\mathrm{tot}, 0}=4 \mu \mathrm{M} ; \mathrm{pH} 7$; with $[\mathrm{Br}]$ from

1460 to $2 \mu \mathrm{M}$ (up to $160 \mu \mathrm{g} / \mathrm{L}$ )). The kinetics of the decrease of the oxidant concentrations are

147 shown in SI (Figure S1) and represented as the sum of $[\mathrm{HOCl}]_{\text {tot }}+[\mathrm{HOBr}]_{\mathrm{tot}}+[\mathrm{HOI}]_{\mathrm{tot}}$; with

$148[\mathrm{HOX}]_{\mathrm{tot}}=[\mathrm{HOX}]+\left[\mathrm{XO}^{-}\right], \mathrm{X}=\mathrm{Cl}, \mathrm{Br}, \mathrm{I}$.

149

150 Figure 1

151

152 As demonstrated in Figure 1, the presence of bromide significantly enhances the kinetics of 153 iodate formation compared to chlorination alone. Half of the iodide was oxidized to iodate after 154360,35 and $13 \mathrm{~min}$, for bromide concentrations of $0,0.5$ and $2 \mu \mathrm{M}$, respectively. The much 155 higher rate of iodate formation by $\mathrm{HOBr}$ (Figure 1a) (half-life of iodide of 4 and 360 min for 156 oxidation by bromine or chlorine, respectively) explains the enhancement observed in 157 presence of bromide during chlorination. This is due to the formation of $\mathrm{HOBr}$ by oxidation of $158 \mathrm{Br}^{-}$by $\mathrm{HOCl}$ (Eq. 19) followed by the reaction of bromine with $\mathrm{HOI}$. Moreover, according to 159 Figure $1 \mathrm{~b}$, the kinetics of iodate formation by bromine is $\mathrm{pH}$-dependent, with the slowest rate 160 occurring at low $\mathrm{pH}$ (7.0). With increasing $\mathrm{pH}$ the rate reached a maximum before decreasing 161 again at higher $\mathrm{pH}$.

162

163 Kinetics and stoichiometry of iodate formation from iodide by $\mathrm{HOBr}$

164 The stoichiometry of the reaction of $\mathrm{HOBr} / \mathrm{BrO}^{-}$with $\mathrm{HOI}^{-} \mathrm{IO}^{-}$to iodate was investigated as a 165 function of $\mathrm{pH}$ and at molar ratios of $[\mathrm{HOBr}]_{\text {tot }}:[1]=4: 1$. Considering the consumption of the 
166 oxidant $\left(\mathrm{HOBr} \mathrm{BrO}^{-}\right)$and its self-decay in water, it was found that $3.0 \pm 0.2 \mathrm{~mol}$ of $\mathrm{HOBr} / \mathrm{BrO}$

167 were consumed per mol of $\mathrm{I}^{-}$oxidized to $\mathrm{IO}_{3}^{-}$(SI, Figure S2). According to the stoichiometry 168 and the mass balance showing quantitative formation of iodate from iodide, it can be assumed 169 that no stable intermediates or $\mathrm{IO}_{4}^{-}$were formed. Therefore, it can be hypothesized that the 170 reaction pathway of formation of iodate through oxidation of iodide by bromine is similar to the 171 one proposed for chlorine (Eqs.1-3). ${ }^{4}$

$172 \mathrm{HOX} / \mathrm{OX}^{-}+\mathrm{I}^{-} \rightarrow \mathrm{HOI}+\mathrm{X}^{-}$

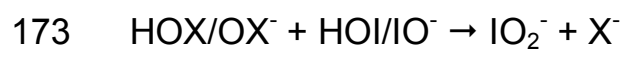

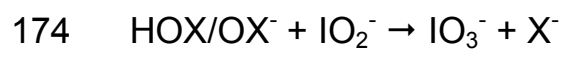

$175 \mathrm{X}=\mathrm{Cl}, \mathrm{Br}$

176 The kinetics of the first step of iodide oxidation by $\mathrm{HOBr}$, i.e., the formation of $\mathrm{HOI}^{\prime} \mathrm{IO}^{-}$, has 177 been determined previously ${ }^{26}$ (Table 2, Eqs. 10 and 11). Under the conditions used, the 178 formation of hypoiodite and hypoiodous acid occurs immediately. Moreover, the species 179 specific rate constants of Eq. 3 are assumed to be high, considering that $\mathrm{IO}_{2}^{-}$does not 180 accumulate in solution. Therefore, the rate limiting step is the oxidation of $\mathrm{HOI}^{-\mathrm{IO}^{-}}$by $181 \mathrm{HOBr}^{-\mathrm{BrO}^{-}}$(Eq. 2) and the rate of iodate formation corresponds to the rate of the reaction (2). 182 To determine the kinetics of the oxidation of iodine by bromine, experiments were performed 183 under pseudo first order conditions $\left([\mathrm{HOBr}]_{\text {tot: }}\left[\mathrm{I}^{-}\right]=20\right)$. The apparent rate constant of reaction 184 (2) can be determined as follows (Eqs. 4-8):

$$
r=\frac{d\left[\mathrm{IO}_{3}^{-}\right]}{d t}=-\frac{d[\mathrm{HOI}]_{t o t}}{d t}
$$

186 where,

$$
r=k_{\text {app }}^{\prime \prime}[\mathrm{HOI}]_{t o t}[\mathrm{HOBr}]_{t o t}
$$

$188 \mathrm{HOBr}$ was introduced in a large excess, hence, $[\mathrm{HOBr}]_{\text {tot }}$ can be considered constant (pseudo 189 first order conditions):

$$
r=k_{a p p}^{\prime}[\mathrm{HOI}]_{t o t} \text { with: } k_{a p p}^{\prime}=k_{a p p}^{\prime \prime}[\mathrm{HOBr}]_{t o t}
$$

191 then,

$$
r=-\frac{d[\mathrm{HOI}]_{t o t}}{d t}=\frac{d\left[\mathrm{IO}_{3}^{-}\right]}{d t}=k_{a p p}^{\prime}[\mathrm{HOI}]_{t o t}
$$


193 The concentration of $\mathrm{HOI}$ after a time $\mathrm{t}$ is calculated as $[\mathrm{HOI}]_{\mathrm{tot}, \mathrm{t}}=[\mathrm{HOI}]_{\mathrm{tot}, 0}{ }^{-}\left[\mathrm{IO}_{3}{ }^{-}\right]_{\mathrm{t}}$ with $[\mathrm{HOl}]_{\mathrm{tot}, 0}$ $194=[1]_{0} ;$ then,

195

$$
\ln \frac{\left[I^{-}\right]_{0}-\left[I O_{3}^{-}\right]_{t}}{\left[I^{-}\right]_{0}}=-k_{\text {app }}^{\prime} t
$$

196

197 The apparent rate constant of the reaction between iodine and bromine was obtained by 198 measuring the kinetics of iodate formation as a function of $\mathrm{pH}$ from 7.0 to 11.5. The slopes of 199 the logarithmic regression lines for the different pH (Eq. 8) (SI, Figure S3) give the value of $200 k_{\text {app }}$. The apparent second order rate constant $k^{\prime \prime}$ app is then obtained by dividing the first order 201 rate constant by the concentration of bromine. The derived apparent second order rate 202 constants of the reaction between iodine and bromine species as a function of the $\mathrm{pH}$ are 203 plotted in Figure 2.

204

205 Figure 2

206

207 The variation of the apparent second order rate constants shows a maximum at the mean of 208 the two pKa values $\left(1 / 2\left(\mathrm{pKa}_{1}+\mathrm{pKa}_{2}\right)=9.6\right)$ of the involved species $\mathrm{HOBr}$ and $\mathrm{HOI}$ $209\left(\mathrm{pKa}_{1}\left(\mathrm{HOBr} / \mathrm{BrO}^{-}\right)=8.8 ; \mathrm{pKa}_{2}\left(\mathrm{HOI}_{/} \mathrm{IO}^{-}\right)=10.4\right)$. This behaviour is common for the reaction of 210 two compounds HA and HB if either the protonated form HA reacts with the deprotonated form $211 \mathrm{~B}^{-}$, or conversely, $\mathrm{A}^{-}$reacts with $\mathrm{HB}^{27}$ From a kinetic point of view, the two reactions $\left(\mathrm{BrO}^{-}+\right.$ $212 \mathrm{HOI}$ and $\mathrm{HOBr}+\mathrm{IO}^{-}$; Eqs. 14 and 14a, Table 2) cannot be distinguished since they have the 213 same $\mathrm{pH}$ dependence. Rather than considering the two reactions in parallel, it is usually 214 assumed that only one of the two pathways is important. From a chemical point of view, $\mathrm{HOBr}$ 215 is a stronger electrophile and $\mathrm{IO}^{-}$is a stronger nucleophile. Therefore, the reaction of $\mathrm{HOBr}$ 216 with $1 \mathrm{O}^{-}$(Table 2, Eq. 14) is considered as the dominant pathway for the reaction of the 217 bromine with the iodine species. Nevertheless, at low or high $\mathrm{pH}, \mathrm{HOBr}+\mathrm{HOI}$ or $\mathrm{OBr}^{-}+\mathrm{IO}^{-}$, 218 respectively, might also be important reactions (see below). Consequently, the reactions 219 considered to represent this reaction step are Eqs. 13-15 (Table 2). 
220

221

222

223

224

225

226

227

228

229

230

231

232

233

234

235

236

237

238

239

240

241

242

243

244

245

246

247

The species specific rate constants were determined by a non-linear least-square regression with the experimental rate constants determined as a function of the $\mathrm{pH}(\mathrm{SI}$, Text S1). The regression curve is represented in Figure 2 and is in good agreement with the profile of the $\mathrm{pH}-$ dependent experimental data. The species specific second order rate constants were determined to be $k\left(\mathrm{HOBr} / \mathrm{IO}^{-}\right)=1.9 \times 10^{6} \mathrm{M}^{-1} \mathrm{~s}^{-1}$ and $k\left(\mathrm{BrO}^{-} / \mathrm{IO}^{-}\right)=1.8 \times 10^{3} \mathrm{M}^{-1} \mathrm{~s}^{-1}$. Based on this model, the reaction between $\mathrm{HOBr}$ and $\mathrm{HOI}$ was negligible with a value tending to zero. For $\mathrm{pH}<7$, a drop of the apparent rate constant was found followed by an increase for smaller $\mathrm{pH}$ values. The increase in the apparent rate constant in more acidic conditions can be attributed to the formation of $\mathrm{Br}_{2}$. The rate constant for the reaction of $\mathrm{Br}_{2}$ with $\mathrm{HOI}$ was estimated to be $1 \times 10^{6} \mathrm{M}^{-1} \mathrm{~s}^{-1}$ and this reaction becomes significant for $\mathrm{pH}<7$ (SI, Text S2).

\section{Modeling the effect of bromide on iodate formation during chlorination}

To validate the kinetics of iodate formation during chlorination of bromide-containing waters, simulations of the reaction system were carried out by a kinetic model (Software Copasi ${ }^{28}$ ). The reaction model is shown in Table 2 (Eqs. 9-25).

\section{Table 2}

The results of the model calculation for of iodide oxidation by bromine are presented in Figure 1b. The experiments performed in basic media were well predicted by the set of reactions taken into account shown in Table 2. However, the model showed a certain deviation compared to the experimental data obtained for $\mathrm{pH}$ 7.0. A small error on the measured $\mathrm{pH}$ value $( \pm 0.1)$ can affect the kinetics of iodate formation significantly. The observed difference between the experiment and model calculations is therefore within the range of experimental error. The model was subsequently applied for modeling iodate formation during chlorination of iodide-containing water in the absence and presence of bromide at $\mathrm{pH} 7$ (lines in Figure 1a) with good agreement with the experimental data. The increase in the rate of iodate formation in the presence of bromide is caused by the formation of bromine through the reaction of chlorine with bromide (Table 2, Eq. 19). $\mathrm{HOBr}$ then oxidizes $\mathrm{HOI}$ to $\mathrm{IO}_{2}^{-}$(more rapidly than $\mathrm{HOCl}$ undertakes this oxidation) and thereby $\mathrm{HOBr}$ is reduced to $\mathrm{Br}^{-}$(Table 2, Eqs. 13-15). 
248 Therefore, bromide acts as a catalyst in the formation of iodate during chlorination. This has 249 been shown previously for the transformation of chlorpyrifos during chlorination. ${ }^{32}$ Bromide 250 catalysis is also known from other oxidation processes such as the enhanced ammonia 251 oxidation during ozonation of ammonia- and bromide-containing waters, and the formation of $252 \mathrm{~N}$-nitrosodimethylamine during ozonation of dimethylsulfoxide- and bromide-containing 253 waters. $^{33,34}$

254 255 lodate formation during chlorination of iodide-containing natural waters

256 To further elucidate the reaction pathways of iodate formation, chlorination experiments were 257 performed with two natural waters spiked with iodide $(0.40 \mu \mathrm{M} \approx 50 \mu \mathrm{g} / \mathrm{L})$ and various 258 concentrations of bromide. Bromide concentrations were in the range of natural waters from $2590.19 \mu \mathrm{M}(15 \mu \mathrm{g} / \mathrm{L})$ up to $6.25 \mu \mathrm{M}(500 \mu \mathrm{g} / \mathrm{L})$. The formation of iodate is presented as a function 260 of the oxidant exposure (sum of chlorine, bromine and iodine exposures) in Figure 3 . This 261 representation takes into account the different rates of consumption of the oxidants due to 262 differences in the water composition.

263

264 Figure 3

265

266 According to Figure 3, as found in ultrapure water, increasing the bromide concentrations in 267 natural waters significantly enhanced the rate of iodate formation. The experiments on both 268 waters were performed at the same $\mathrm{pH}(8)$ to avoid an effect of this parameter on the kinetics 269 of iodate formation. The main difference between the two waters was the DOC level: Lake 270 Greifensee water (3.5 mg C/L) had a DOC concentration that was 3 times higher than the DOC 271 concentration of Lake Zurich water (1.2 mg C/L). Comparison of Figures $3 a$ and $b$ shows that 272 the rate of iodate formation was higher for the water with the lower DOC concentration at the 273 same bromide concentration. Hypoiodous and hypobromous acids are scavenged to a higher 274 proportion when the concentration of dissolved organic matter (DOM) is higher. This is 275 reflected by the fact that the iodate yield in the natural waters is not $100 \%$ based on the initial 
276 iodide concentration. In addition to the kinetic enhancement, it is important to note that a 277 higher bromide level also improves the relative conversion of iodide to iodate by lowering the 278 effect of the competitive reactions with DOM. The faster reaction of bromine species compared 279 to chlorine species with hypoiodous acid decreases the life-time of $\mathrm{HOI}$, thereby reducing its 280 likelihood of reaction with DOM and favoring iodate as a sink for iodine. The stability of the 281 oxidants $(\mathrm{HOCl}+\mathrm{HOBr}+\mathrm{HOI})$ was also influenced by the bromide concentration (SI, Figure 282 S4). An increase in the consumption rate of the total oxidant concentration was observed with 283 increasing bromide concentration. In natural waters, this can mainly be explained by the higher 284 reactivity of $\mathrm{HOBr}$ compared to $\mathrm{HOCl}$ towards $\mathrm{DOM}^{6,35}$ During chlorination, a substantial 285 portion of bromide disappeared and was probably incorporated into organic matter (SI, Figure 286 S5). This fraction was different for the two waters and was independent of the initial bromide 287 concentration. Bromide in these waters decreased about 50 and $40 \%$ based on the initial 288 concentration in Lake Zurich and Lake Greifensee waters, respectively. Modeling of the effect 289 of bromide on iodate formation during chlorination of iodide-containing natural waters was 290 difficult due to the unknown speciation of the different oxidant species, $\mathrm{HOCl}, \mathrm{HOBr}$ and $\mathrm{HOI}$, 291 and lack of information on the reactivity of those species with DOM which is different for each 292 natural water.

293 To compare the influence of the type of DOM on iodate formation, experiments with natural 294 waters from different origins (lakes, reservoirs and a river from both Switzerland and Australia; 295 Table 1) were performed. Chlorination experiments were conducted at $\mathrm{pH} 8.0$ with the natural 296 waters adjusted to the same DOC concentration $(1.2 \mathrm{mg} \mathrm{C} / \mathrm{L})$, with iodide and bromide 297 concentrations of $50 \pm 2$ and $105 \pm 5 \mu \mathrm{g} / \mathrm{L}(0.4$ and $1.3 \mu \mathrm{M})$, respectively. The formation of 298 iodate as a function of the oxidant exposures is presented in Figure 4.

Figure 4

302 Despite the same experimental conditions ( $\left.\mathrm{pH}, \mathrm{Il}^{-}\right],\left[\mathrm{Br}^{-}\right], \mathrm{DOC}$ concentration), the kinetics of 303 iodate formation varied depending on the water type. In particular, the experiment performed 
304 using the Great Southern Reservoir water showed completely different iodate formation. 305 Different types of DOM have different reactivities towards hypohalous acids and are 306 responsible for differences in extent and rate of iodate formation due to incorporation of 307 halogens into the DOM. In fact, the kinetics of iodate formation generally decreased with 308 increasing SUVA (SI, Figure S6). This is likely related to the more aromatic character of the 309 organic matter (higher SUVA), which constitutes a target for quenching the moieties HOI and $310 \mathrm{HOBr}$, thereby increasing the competition of the DOM for consumption of the HOI versus 311 oxidation of $\mathrm{HOI}$ to iodate. However, the SUVA alone does not explain completely the 312 differences in the kinetics of iodate formation. For example, Lake Zurich and Great Southern 313 River waters showed the same trend for iodate formation but had quite different SUVA values 314 (2.6 and 4.1, respectively). Therefore, SUVA can only serve as a very general parameter to 315 understand the relative kinetics of iodate formation in natural waters and more detailed 316 structural information on DOM would be needed to draw more quantitative conclusions. As 317 noted previously, bromide incorporation into organic matter differs from one water source to 318 another. In the five investigated waters, bromide incorporation was found to vary from 30 to $31970 \%$ without any correlation to the kinetics of iodate formation (results not shown). However, 320 the experiments performed at two DOC concentrations for Lake Griefensee (1.2 and $3.5 \mathrm{mg}$ $321 \mathrm{C} / \mathrm{L}$ ) show that the kinetics of iodate formation (Figure $3 \mathrm{~b}$ and 4 ) and the incorporation of 322 bromine was related to the DOC concentration. Half of the maximum yield of iodate (i.e. 323 formation of $0.2 \mu \mathrm{M}$ of iodate) was reached for an oxidant exposure of 7 and $24 \mathrm{mg} \mathrm{Cl}_{2} / \mathrm{L} \times$ $324 \mathrm{~min}$, for a DOC concentration of 1.2 and $3.5 \mathrm{mg} \mathrm{C} / \mathrm{L}$, respectively. Moreover, the incorporation 325 of bromine into organic matter was higher for the higher organic matter content (30 and 40\% 326 for DOC concentrations of 1.2 and $3.5 \mathrm{mg} \mathrm{C/L}$, respectively). The observations of iodate 327 formation and bromide incorporation into organic matter indicate a significant dependence on 328 the DOC concentration. Therefore, the conversion factor of iodide to iodate could be much 329 lower in waters rich in organic matter. 


\section{Formation of iodo-trihalomethanes (I-THMs)}

334 Trihalomethane formation may serve as a model for the formation of halo-organic compounds. 335 Chloramination with a sufficient free chlorine contact time followed by ammonia addition, rather 336 than preformed monochloramine, has been previously suggested ${ }^{8,21,22}$ as a mitigation strategy 337 for the minimization of I-DBPs, since exposure to free chlorine should promote the formation of 338 iodate. This mitigation process was tested on one of the natural waters (Great Southern River, 339 after dilution and spiking: $\left[\mathrm{I}^{\mathrm{I}}\right]=50 \mu \mathrm{g} / \mathrm{L} ; \mathrm{pH}$ 8; $\left.\mathrm{DOC}=1.2 \mathrm{mg} \mathrm{C} / \mathrm{L}\right)$. The free chlorine contact 340 time was varied such that the full range of conversion of iodide to iodate (from 0 up to nearly $34190 \%$ ) was achieved to elucidate the optimum conditions for mimimal formation of I-THMs. This 342 was done for three different bromide concentrations (40, 100 and $200 \mu \mathrm{g} / \mathrm{L})$. After a certain 343 chlorine contact time $(0,2,5,10$ and $20 \mathrm{~min})$, ammonia was added to reduce the formation of 344 bromo- and chloro-organic compounds. The formation of trihalomethanes, the four regulated 345 THMs (THM4) and I-THMs, was analysed after 24 hours. Figure 5 presents the iodine 346 incorporation into I-THMs and the corresponding iodate formation. A detailed speciation of 347 trihalomethanes is given in SI (Figures S7 and S8). For the calculation of the incorporation of 348 iodine, the molar concentrations of individual I-THMs were multiplied by the number of iodine 349 atoms in the I-THM. With this value, the percentage of iodine incorporated into the I-THMs can 350 be compared to the percentage of iodine yielding $\mathrm{IO}_{3}$.

352 Figure 5 353

354 Considering the monochloramination experiment (no free chlorine contact time, $t=0$ min in 355 Figure 5), only a few THM4 were formed with traces of brominated THMs, as monochloramine 356 hardly oxidizes bromide (SI, Figures S7 and S8). Although the I-THMs were predominant in 357 this case compared to the THM4, a relatively low incorporation of iodine into I-THMs of around $3586 \%$ of the initial iodide content, independent of the bromide concentration was observed. In this 359 process, iodoform was formed in a relatively high concentration, representing up to $90 \%$ of the 
360 iodine incorporation into I-THMs. These results are in accordance with those previously 361 published $^{5,9,21,22,36}$ in which chloramination of raw waters showed substantial formation of 362 iodoform.

363 The formation and the speciation of iodinated THMs depend on the free chlorine contact time 364 and the bromide concentration. The iodine incorporation into I-THMs increased for a short 365 chlorination time compared to chloramination but decreased for higher free chlorine exposures. 366 The lower formation of I-THMs with increasing free chlorine contact time was correlated with 367 the conversion of iodide to iodate. According to Figure 5, the iodine incorporation was lowered 368 from 18 to $2 \%$ of the initial iodide content, while the iodate concentration increased from 10 to 369 nearly $90 \%$, for an increase of the prechlorination time from 2 up to 20 min in the presence of $370200 \mu \mathrm{g} / \mathrm{L}$ of bromide. Moreover, increasing concentrations of bromide clearly reduced the 371 formation of I-THMs by favoring the formation of iodate. For the experiments performed with 372 the highest prechlorination time, an increase of the bromide level from 40 to $200 \mu \mathrm{g} / \mathrm{L}$ resulted 373 in a decrease of the iodine incorporated in I-THMs by a factor $>4$ and an improvement of 374 iodide conversion to iodate from 45 to nearly $90 \%$ of the initial iodide concentration. At the 375 same time, the formation of $\mathrm{Br}$-THMs was kept low, with a bromine incorporation between 4.5 376 and more than 10 times lower than the one observed during the $24 \mathrm{~h}$-chlorination performed 377 under the same conditions for varying $\mathrm{Br}^{-}$concentrations. The highest formation of THM4 378 observed for the chlorine-ammonia process occurred for the highest free chlorine contact time 379 and highest bromide concentration. However, this concentration $(9 \mu \mathrm{g} / \mathrm{L})$ was significantly 380 lower than the one observed for the $24 \mathrm{~h}$-chlorination (around $40 \mu \mathrm{g} / \mathrm{L}$ ) (SI, Figure S8 and Table 381 S1). Considering the increasing iodate formation with increasing prechlorination time (Figure 382 5), the higher formation of I-THMs after a short prechlorination time compared to the 383 chloramination process was not expected. ${ }^{5}$ This behaviour was also noticed by Jones et al. ${ }^{21}$ 384 who showed a higher formation of I-THMs by chlorination than by the chloramination process 385 in some cases. This was attributed to the additional formation of brominated I-THMs during 386 chlorination which are not formed during chloramination. In our experiments, the formation of 387 brominated I-THMs effectively occurred with chlorination (SI, Figure S7) and contributed to the 
overall increase of I-THMs, but the formation of iodoform also increased with a short prechlorination time. As shown in a previous study, ${ }^{5}$ the formation of iodoform readily depends on the chlorination dose and exposure, decreasing with an increasing exposure. In our study, the highest concentrations of iodoform were observed for the smaller prechlorination contact times and exposures (from 0 to $5 \mathrm{~min}$ ). Thereafter, the concentration of this product decreased with increasing chlorine exposure. The same trend was also observed for the highly iodinated compounds $\left(\mathrm{CHCll}_{2}\right.$ and $\left.\mathrm{CHBrl}_{2}\right)$. Therefore, increased chlorination can limit the formation of the highly iodinated THMs, and especially the formation of $\mathrm{CHI}_{3}$, which may be problematic due to its taste and odor. ${ }^{10}$ It can also be expected that highly toxic mono-iodinated compounds, such as iodo acetic acids, will behave in the same manner. However, the chlorine dose is an important parameter: the prechlorination exposure should be high enough to transform iodide into iodate and avoid the formation of high concentrations of iodinated compounds. In our experiments, the formation of I-THMs was decreased to a large extent after 10 minutes for the experiment performed with the higher bromide concentration; a longer contact time was needed in the case of lower concentrations of bromide. Furthermore, in addition to the formation of I-THMs, more information is needed about the formation of other iodo-organic compounds, especially iodoacetic acid, under realistic conditions without omitting the role of bromide. During chlorination, iodate formation was controlled by $\mathrm{HOBr}$ even at low bromide levels. Considering a chlorine dose of $1 \mathrm{mg} \mathrm{Cl} / \mathrm{L}$ at $\mathrm{pH} 7$, a concentration of approximately $25 \mu \mathrm{g} / \mathrm{L}$ of bromide is sufficient to induce half of the iodate formation through the reaction of $\mathrm{HOI}$ with $\mathrm{HOBr}$. This concentration drops to $<10 \mu \mathrm{g} / \mathrm{L}$ for $\mathrm{pH} 8$.

\section{Practical implications}

A process based on free chlorine followed by chloramine to reduce the formation of I-organics has been proposed in several studies..$^{4,9,11,21,22,36-38}$ Our study reveals that bromide plays an important role in this process, notably by enhancing the preferred conversion of iodide to iodate. The balance between the formation of iodate and iodoorganic compounds formation depends on the water quality, i.e. the concentration and nature of the natural organic matter, the bromide concentration and the chlorine consumption rate. To determine the optimum pre- 
416 chlorine exposure, we propose an assessment of iodate formation. In fact, the plot of I417 incorporation vs. iodate formation (SI, Figure S9) shows that, under our experimental 418 conditions, the formation of I-THMs was minimal for a conversion of $\geq 60 \%$ of iodide to iodate, 419 independent of the bromide level. Since we have a limited data set, more information is 420 needed to validate this procedure.

\section{Acknowledgments}

422 The authors would like to acknowledge funding and support from the Australian Research 423 Council (ARC LP100100285), Water Corporation (WA), Curtin University, Eawag and Water 424 Quality Research Australia.

\section{Supporting Information Available}

426 Two texts, one table and nine figures with further information addressing calculations and 427 additional data. This information is available free of charge via the Internet at 428 http://pubs.acs.org/ .

\section{References}

430 (1) Garland, J. A.; Elzerman, A. W.; Penkett, S. A., The mechanism for dry deposition of 431 ozone to seawater surfaces. J. Geophys. Res. 1980, 85, (C12), 7488-7492.

432 (2) Kumar, K.; Day, R. A.; Margerum, D. W., Atom-transfer redox kinetics: general-acid433 assisted oxidation of iodide by chloramines and hypochlorite. Inorg. Chem. 1986, 25, 43444344350.

435 (3) Nagy, J. C.; Kumar, K.; Margerum, D. W., Non metal redox kinetics: Oxidation of iodide 436 by hypochlorous acid and by nitrogen trichloride measured by the pulsed-accelerated-flow 437 method. Inorg. Chem. 1988, 27, (16), 2773-2780.

438 (4) Bichsel, Y.; von Gunten, U., Oxidation of iodide and hypoiodous acid in the disinfection 439 of natural waters. Environ. Sci. Technol. 1999, 33, 4040-4045.

440 (5) Bichsel, Y.; von Gunten, U., Formation of iodo-trihalomethanes during disinfection and 441 oxidation of iodide containing waters. Environ. Sci. Technol. 2000, 34, 2784-2791.

442 (6) Hua, G.; Reckhow, D. A.; Kim, J., Effect of bromide and iodide ions on the formation 443 and speciation of disinfection by-products during chlorination. Environ. Sci. Technol. 2006, 40, 444 3050-3056.

445 (7) Plewa, M. J.; Wagner, E. D.; Richardson, S. D.; Thruston, A. D.; Woo, Y. T.; Mckague, 446 A. B., Chemical and biological characterization of newly discovered iodoacetic drinking water 447 disinfection by-products. Environ. Sci. Technol. 2004, 38, (18), 4713-4722. 
448 (8) Richardson, S. D.; Fasano, F.; Ellington, J. J.; Crumley, G. F.; Buettner, K. M.; Evans, 449 J. J.; Blount, B. C.; Silva, L. K.; Waite, T. J.; Luther, G. W.; McKague, B. A.; Miltner, R. J.; Wagner, E. D.; Plewa, M. J., Occurence and mammalian cell toxicity of iodinated disinfection by-products in drinking water. Environ. Sci. Technol. 2008, 42, 8330-8338.

452

(9) Hansson, R. C.; Henderson, M. J.; Jack, P.; Taylor, R. D., lodoform taste complaints in 453 chloramination. Water Res. 1987, 21, (10), 1265-1271.

454

455

456

(10) Cancho, B.; Fabrellas, C.; Diaz, A.; Ventura, F., Determination of the odor threshold concentrations of iodinated trihalomethanes in dinking water. J. Agric. Food Chem. 2001, 49, 1881-1884.

457 (11) Krasner, S. W.; Weinberg, H. S.; Richardson, S. D.; Pastor, S. J.; Chinn, R.; Sclimenti, 458 M. J.; Onstad, G. D.; Thruston, A. D., Occurence of new generation of disinfection by-products. 459 Environ. Sci. Technol. 2006, 40, 7175-7185.

460 (12) Karpel Vel Leitner, N.; Vessela, J.; Doré, M.; Legube, B., Chlorination and formation of 461 organoiodinated compounds: The important role of ammonia. Environ. Sci. Technol. 1998, 32, 462 1680-1685.

463 (13) Bürgi, H.; Schaffner, T.; Seiler, J. P., The toxicology of iodate: A review of the literature. 464 Thyroid 2001, 11, (5), 449-456.

465 (14) Kumar, K.; Margerum, D. W., Kinetics and mechanism of general-acid-assisted 466 Oxidation of bromide by hypochlorite and hypochlorous acid. Inorg. Chem. 1987, 26, 27064672711.

468

(15) Gallard, H.; Pellizzari, F.; Croué, J. P.; Legube, B., Rate constants of reactions of 469 bromine with phenols in aqueous solution. Water Res. 2003, 37, 2883-2892.

470 (16) Guo, S. C.; Lin, F., The bromination kinetics of phenolic compounds in aqueous 471 solution. J. Hazard. Mater. 2009, 170, 645-651.

472 (17) Acero, J. L.; Piriou, P.; von Gunten, U., Kinetics and mechanism of formation of 473 bromophenols during drinking water chlorination: Assesment of taste and odor development. 474 Water Res. 2005, 39, 2979-2993.

475

476

477

(18) Lee, Y.; von Gunten, U., Transformation of 17a-Ethynilestradiol during water chlorination. effect of bromide on kinetics, products and transformation pathways. Environ. Sci. Technol. 2009, 43, 480-487.

478 (19) Cowman, A. G.; Singer, P. C., Effect of bromide ion on haloacetic speciation resulting 479 from chlorination and chloramination of aquatic humic substances. Environ. Sci. Technol. 480 1996, 30, 16-24.

481

482

483

(20) Chowdhury, S.; Champagne, P.; McLellan, P. J., Investigating effects of bromide ions on trihalomethanes and developing model for predicting bromodichloromethane in drinking water. Water Res. 2010, 44, 2349-2359.

484

485

(21) Jones, D. B.; Saglam, A.; Triger, A.; Song, H.; Karanfil, T., I-THM formation and

486

487

488

489 speciation: preformed monochloramine versus prechloramination followed by ammonia addition. Environ. Sci. Technol. 2011, 45, 10429-10437.

490

(22) Jones, D. B.; Saglam, A.; Song, H.; Karanfil, T., The impact of bromide/iodide concentration and ratio on iodinated trihalomethane formation and speciation. Water Res. 2012, 46, 11-20.

(23) Rodier, J.; Legube, B.; Merlet, N., L'analyse de l'eau. 9 ed. ed.; Dunod: 2009; p 1600.

(24) Salhi, E.; von Gunten, U., Simultaneous determination of bromide, bromate and nitrite in low $\mu \mathrm{g} \mathrm{I}^{-1}$ levels by ion chromatography without sample pretreatment. Water Res. 1999, 33, 3239-3244. 
(25) Allard, S.; Charrois, J. W. A.; Joll, C. A.; Heitz, A., Simultaneous analysis of 10 trihalomethanes at nanogram per liter levels in water using solid-phase microextraction and gas chromatography mass spectrometry. J. Chromatogr. A 2012, 1238, 15-21.

(26) Troy, R. C.; Margerum, D. W., Non-Metal Redox Kinetics: Hypobromite and Hypobromous Acid Reactions with lodide and with Sulfite and the Hydrolysis of Bromosulfate. Inorg. Chem. 1991, 30, 3538-3543.

500

(27) von Gunten, U.; Oliveras, Y., Kinetic of the reaction between hydrogen peroxide and hypobromous acid: implication on water treatment and natural systems. Water Res. 1997, 31,

502 900-906.

503 (28) Hoops, S.; Sahle, S.; Gauges, R.; Lee, C.; Pahle, J.; Simus, N.; Singhal, M.; Xu, L.; 504 Mendes, P.; Kummer, U., COPASI - a COmplex PAthway SImulator. Bioinformatics 2006, 22, 505 3067-3074.

506 (29) Haag, W. R.; Hoigné, J., Ozonation of bromide-containing waters: kinetics of formation 507 of hypobromous acid and bromate. Environ. Sci. Technol. 1983, 17, 261-267.

508 (30) Bichsel, Y.; von Gunten, U., Hypoiodous acid: Kinetics of the buffer-catalysed 509 dispropornation. Water Res. 2000, 34, (12), 3197-3203.

510 (31) Weast, R. C., Handbook of Chemistry and Physics. CRC Press: Boca Raton: FL, 1984.

511 (32) Duirk, S. E.; Tarr, J. C.; Colette, T. W., Chlorpyrifos transformation by aqueous chlorine 512 in the presence of bromide and natural organic matter. J. Agric. Food Chem. 2008, 56, 13285131335.

514 (33) Haag, W. R.; Hoigné, J.; Bader, H., Improved ammonia oxidation by ozone in the 515 presence of bromide ion during water treatment. Water Res. 1984, 18, 1125-1128.

516 (34) von Gunten, U.; Salhi, E.; Schmidt, C. K.; Arnold, W. A., Kinetics and mechanisms of N517 nitrosodimethylamine formation upon ozonation of $\mathrm{N}, \mathrm{N}$-dimethylsulfamide-containing waters: 518 bromide catalysis. Environ. Sci. Technol. 2010, 44, 5762-5768.

519 (35) Westerhoff, P.; Chao, P.; Mash, H., Reactivity of natural organic matter with aqueous 520 chlorine and bromine. Water Res. 2004, 38, 1502-1513.

521 (36) Hua, G.; Reckhow, D. A., Comparison of disinfection byproduct formation from chlorine 522 and alternative disinfectants. Water Res. 2007, 41, 1667-1678.

523 (37) Ding, G.; Zhang, X., A picture of polar iodinated byproducts in drinking water by 524 (UPLC/)ESI-tqMS. Environ. Sci. Technol. 2009, 43, 9287-9293.

525 (38) Krasner, S. W., The formation and control of emerging disinfection by-products of 526 health concern. Phil. Trans. R. Soc. A 2009, 367, 4077-4095.

527

528

529

530 
531

532 Table 1. Natural water characteristics.

\begin{tabular}{lcccc}
\hline & DOC $(\mathrm{mg} \mathrm{C/L})$ & $\begin{array}{c}\text { SUVA } \\
(\mathrm{L} / \mathrm{mg} \mathrm{C.m})\end{array}$ & $\mathrm{I}^{-}(\mu \mathrm{g} / \mathrm{L})$ & $\mathrm{Br}^{-}(\mu \mathrm{g} / \mathrm{L})$ \\
\hline Lake Zurich & 1.2 & 2.6 & $<10$ & 15 \\
Lake Greifensee & 3.5 & 1.8 & $<10$ & 50 \\
North West Reservoir & 2.8 & 1.7 & 31 & 168 \\
Great Southern River & 12.0 & 4.1 & 17 & 412 \\
Great Southern Reservoir & 20.0 & 4.9 & $<10$ & 400 \\
\hline
\end{tabular}

533 
534 Table 2. Rate constants for the reactions occurring in the chlorine-bromide-iodide system.

535

\begin{tabular}{llllll}
\hline Eq. & Reaction & $\begin{array}{c}\text { Rate } \\
\text { constants } \\
\left(M^{-1} s^{-1}\right)\end{array}$ & pKa & $\begin{array}{c}k^{\prime \prime}{ }_{\text {app }}\left(M^{-1} s^{-1}\right) \\
\text { pH } 7\end{array} \quad$ pH 8 & References
\end{tabular}

\begin{tabular}{|c|c|c|c|c|c|c|}
\hline 9 & $\mathrm{BrO}^{-}+\mathrm{H}^{+} \leftrightarrows \mathrm{HOBr}$ & & 8.8 & & & 29 \\
\hline 10 & $\mathrm{HOBr}+\mathrm{I}^{-} \rightarrow \mathrm{HOI}+\mathrm{Br}^{-}$ & $5.0 \times 10^{9}$ & & & & 26 \\
\hline 11 & $\mathrm{BrO}^{-}+\mathrm{I}^{-} \rightarrow \mathrm{IO}^{-}+\mathrm{Br}^{-}$ & $6.8 \times 10^{5}$ & & & & 26 \\
\hline 12 & $\mathrm{IO}^{-}+\mathrm{H}^{+} \leftrightarrows \mathrm{HOI}$ & & 10.4 & & & 30 \\
\hline 13 & $\mathrm{HOBr}+\mathrm{HOI} \rightarrow \mathrm{IO}_{2}^{-}+\mathrm{Br}^{-}+2 \mathrm{H}^{+}$ & $\begin{array}{c}\text { Not } \\
\text { significant }\end{array}$ & & & & This work \\
\hline 14 & $\mathrm{HOBr}+\mathrm{IO}^{-} \rightarrow \mathrm{IO}_{2}^{-}+\mathrm{Br}^{-}+\mathrm{H}^{+}$ & $1.9 \times 10^{6}$ & & 740 & 6500 & This work \\
\hline $14 a$ & $\mathrm{BrO}^{-}+\mathrm{HOI} \rightarrow \mathrm{IO}_{2}^{-}+\mathrm{Br}^{-}+\mathrm{H}^{+}$ & - & & & & a \\
\hline 15 & $\mathrm{BrO}^{-}+1 \mathrm{IO}^{-} \rightarrow \mathrm{IO}_{2}^{-}+\mathrm{Br}^{-}$ & $1.8 \times 10^{3}$ & & 12 & 1030 & This work \\
\hline 16 & $\mathrm{HOBr}+\mathrm{IO}_{2}^{-} \rightarrow \mathrm{IO}_{3}^{-}+\mathrm{Br}^{-}+\mathrm{H}^{+}$ & High & & & & $\begin{array}{l}\text { Suggested in } \\
\text { this work }\end{array}$ \\
\hline 17 & $\mathrm{BrO}^{-}+\mathrm{IO}_{2}^{-} \rightarrow \mathrm{IO}_{3}^{-}+\mathrm{Br}^{-}$ & High & & & & $\begin{array}{l}\text { Suggested in } \\
\text { this work }\end{array}$ \\
\hline 18 & $\mathrm{ClO}^{-}+\mathrm{H}^{+} \leftrightarrows \mathrm{HOCl}$ & & 7.53 & & & 31 \\
\hline 19 & $\mathrm{HOCl}+\mathrm{Br}^{-} \rightarrow \mathrm{HOBr}+\mathrm{Cl}^{-}$ & 1550 & & & & 14 \\
\hline 20 & $\mathrm{ClO}^{-}+\mathrm{Br}^{-} \rightarrow \mathrm{BrO}^{-}+\mathrm{Cl}^{-}$ & $9 \times 10^{-4}$ & & & & 14 \\
\hline 21 & $\mathrm{HOCl}+\mathrm{I}^{-} \rightarrow \mathrm{HOI}+\mathrm{Cl}^{-}$ & $4.3 \times 10^{8}$ & & & & 3 \\
\hline 22 & $\mathrm{HOCl}+\mathrm{HOI} \rightarrow \mathrm{IO}_{2}^{-}+\mathrm{Cl}^{-}+2 \mathrm{H}^{+}$ & 8.2 & & & & 4 \\
\hline 23 & $\mathrm{ClO}^{-}+\mathrm{HOI} \rightarrow \mathrm{IO}_{2}^{-}+\mathrm{Cl}^{-}+\mathrm{H}^{+}$ & 52 & & & & 4 \\
\hline 24 & $\mathrm{HOCl}+\mathrm{IO}_{2}^{-} \rightarrow \mathrm{IO}_{3}^{-}$ & High & & & & $\begin{array}{l}\text { Suggested in } \\
\text { this work }\end{array}$ \\
\hline 25 & $\mathrm{ClO}^{-}+\mathrm{IO}_{2}^{-} \rightarrow \mathrm{IO}_{3}^{-}+\mathrm{Cl}^{-}$ & High & & & & $\begin{array}{l}\text { Suggested in } \\
\text { this work }\end{array}$ \\
\hline
\end{tabular}

${ }^{a}$ Reaction $14 a$ is not taken into account as reaction 14 describes the behaviour of these 537 species as $\mathrm{f}(\mathrm{pH})$.

538

539 


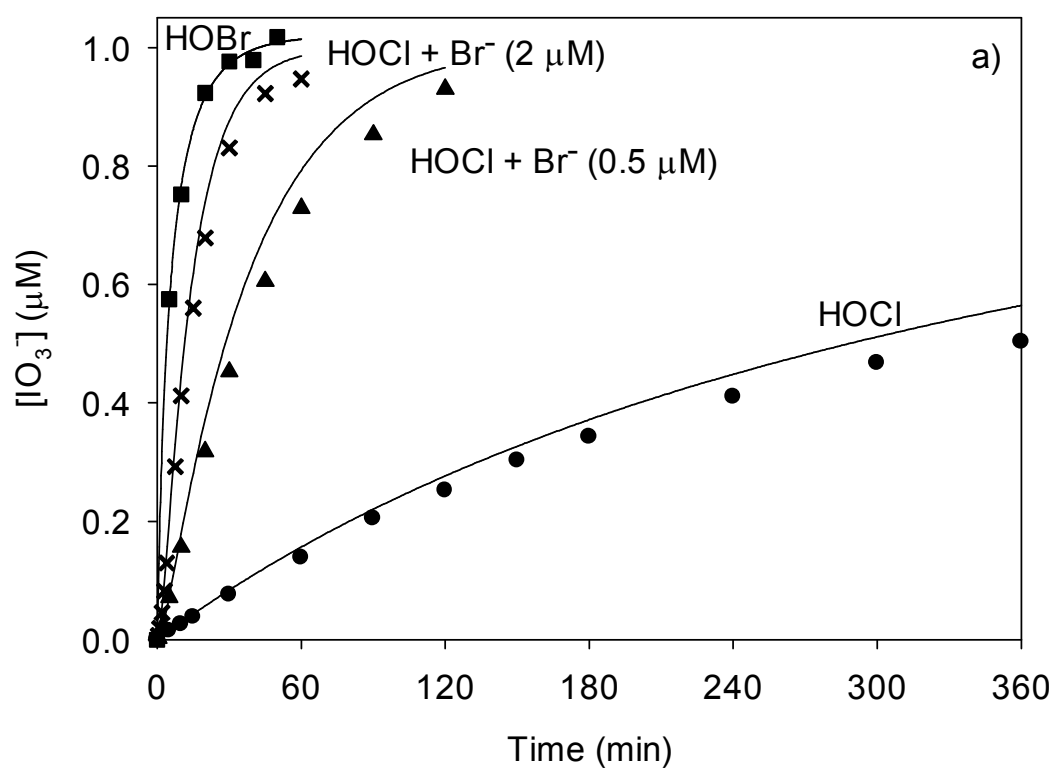

542

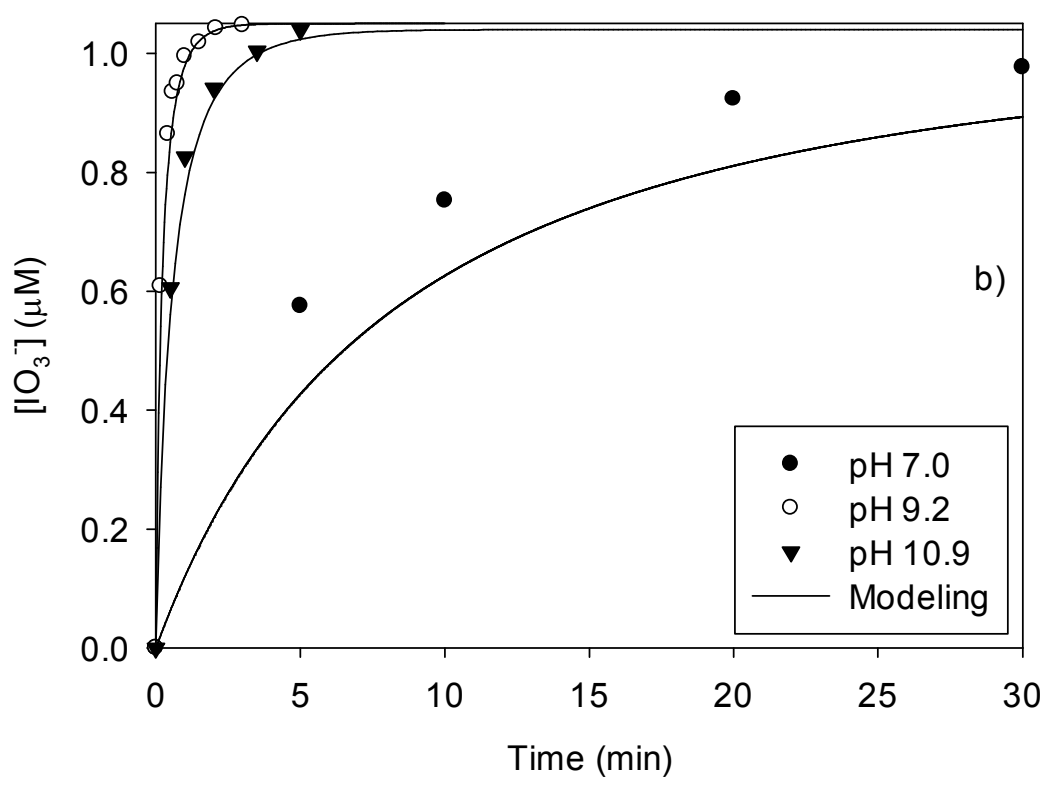

543

544 Figure 1. Kinetics of iodate formation from iodide-containing waters: a) during chlorination in 545 presence of various concentrations of bromide or during bromination (ultrapure water, $\mathrm{pH} 7.0 \pm$ 5460.1 (phosphate buffer, $5 \mathrm{mM}$ ); $\left[\mathrm{l}^{-}\right]_{0}=1 \mu \mathrm{M} ;\left[\mathrm{Br}^{r}\right]_{0}=0.5$ or $2 \mu \mathrm{M},[\mathrm{HOBr}]_{0}$ or $[\mathrm{HOCl}]_{0}=4 \mu \mathrm{M}$ ); b) 547 during bromination at various $\mathrm{pH}$ values $\left(\left[\mathrm{I}^{-}\right]_{0}=1 \mu \mathrm{M}\right.$; $[\mathrm{HOBr}]_{0}=4 \mu \mathrm{M}$ (phosphate, borate or 548 carbonate buffer, $5 \mathrm{mM})$ ). Symbols: experimental data; Lines: Modeling considering the 549 reactions in Table 2 (see text). 


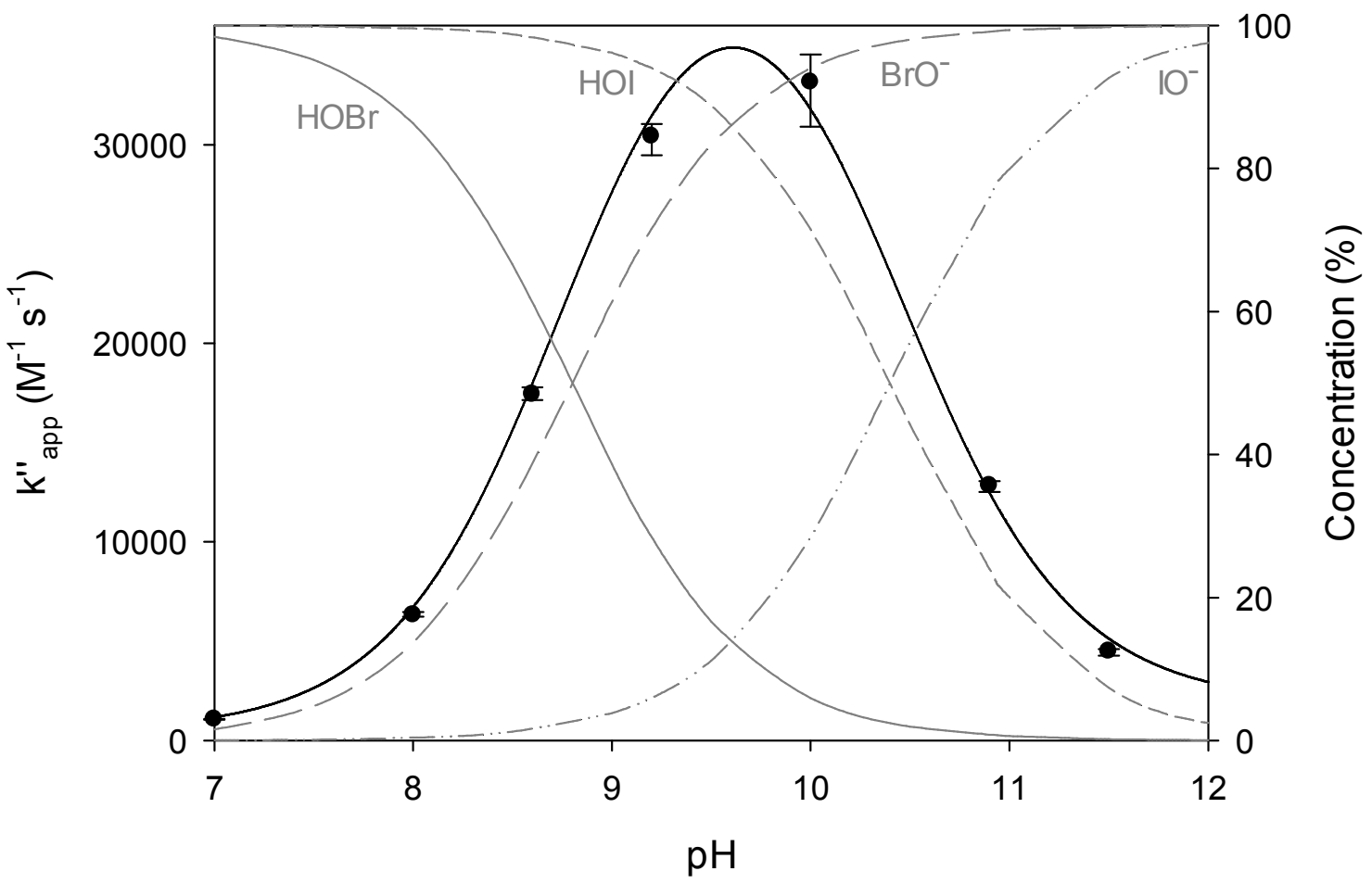

Figure 2. $\mathrm{pH}$ dependence of the relative distribution of the main aqueous bromine and iodine species (grey) and the apparent second-order rate constant for the reaction of $\mathrm{HOBr}$ with $\mathrm{HOI}$ $\left.\left(\mathrm{pKa}_{1}(\mathrm{HOBr} / \mathrm{BrO})^{-}\right)=8.8 ; \mathrm{pKa}_{2}\left(\mathrm{HOI} / / O^{-}\right)=10.4\right)($ black $)$ : experimental data; - : model 555 calculations (see text). 

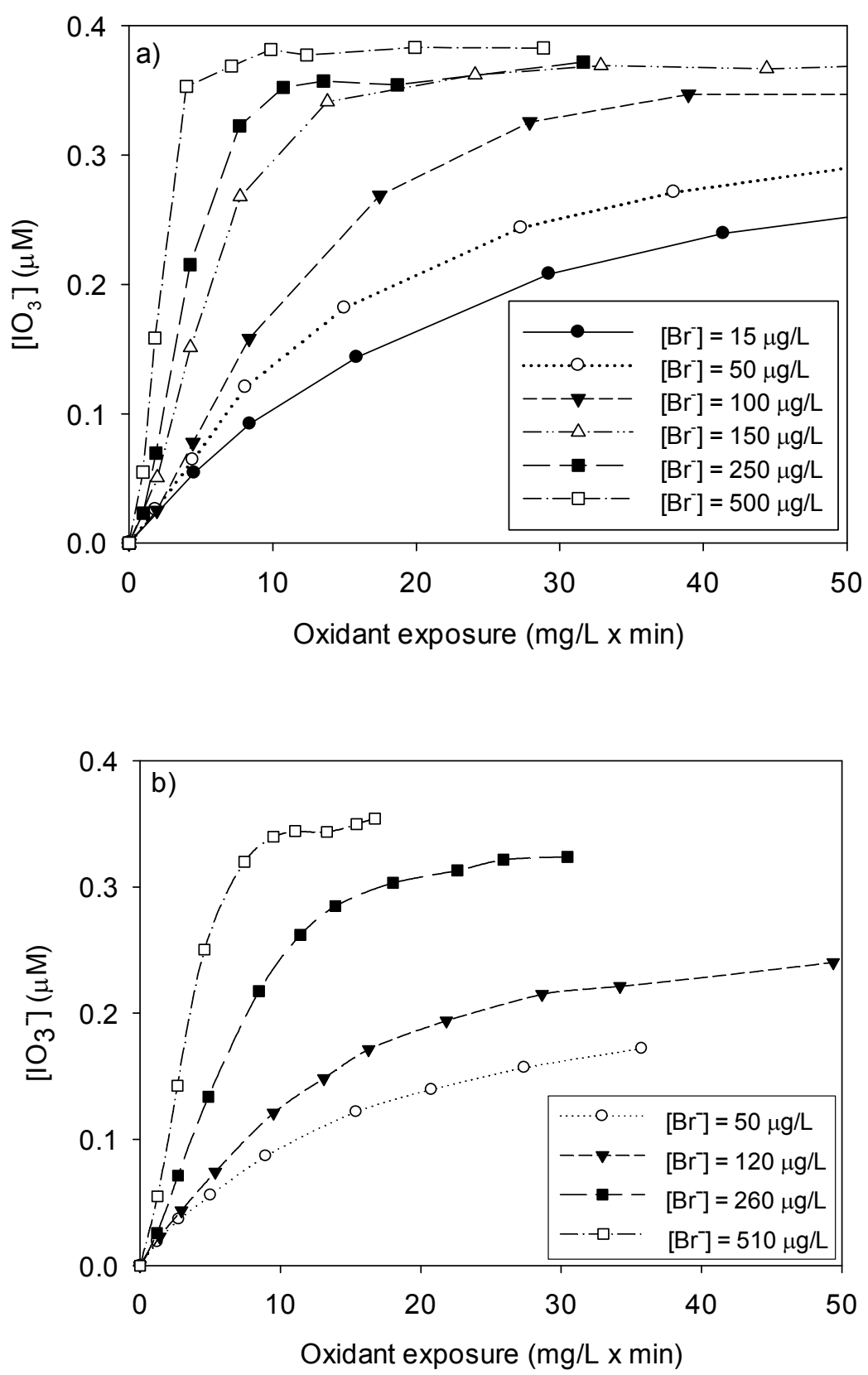

558 Figure 3. Influence of bromide concentration on iodate formation during chlorination of iodidecontaining natural waters $\left(\left[\mathrm{I}^{\mathrm{l}}\right]_{0}=0.4 \mu \mathrm{M} ; 50 \mu \mathrm{g} / \mathrm{L}\right)$ at $\mathrm{pH}$ 8.0. a) Lake Zurich water: $[\mathrm{HOCl}]_{0}=$ $1.0 \mathrm{mg} \mathrm{Cl} / \mathrm{L} ; \mathrm{DOC}=1.2 \mathrm{mg} \mathrm{C} / \mathrm{L} ;\left[\mathrm{Br}^{-}\right]_{0}=15-500 \mu \mathrm{g} / \mathrm{L}(0.19-6.3 \mu \mathrm{M})$. b) Lake Greifensee water: $\left[\mathrm{HOCl}_{0}=1.8 \mathrm{mg} \mathrm{Cl} / \mathrm{L} ; \mathrm{DOC}=3.5 \mathrm{mg} \mathrm{C} / \mathrm{L} ;\left[\mathrm{Br}^{-}\right]_{0}=50-510 \mu \mathrm{g} / \mathrm{L}(0.63-6.4 \mu \mathrm{M})\right.$. Lines are used to guide the eye. Oxidant: $[\mathrm{HOCl}]+[\mathrm{HOBr}]+[\mathrm{HOl}]$. 


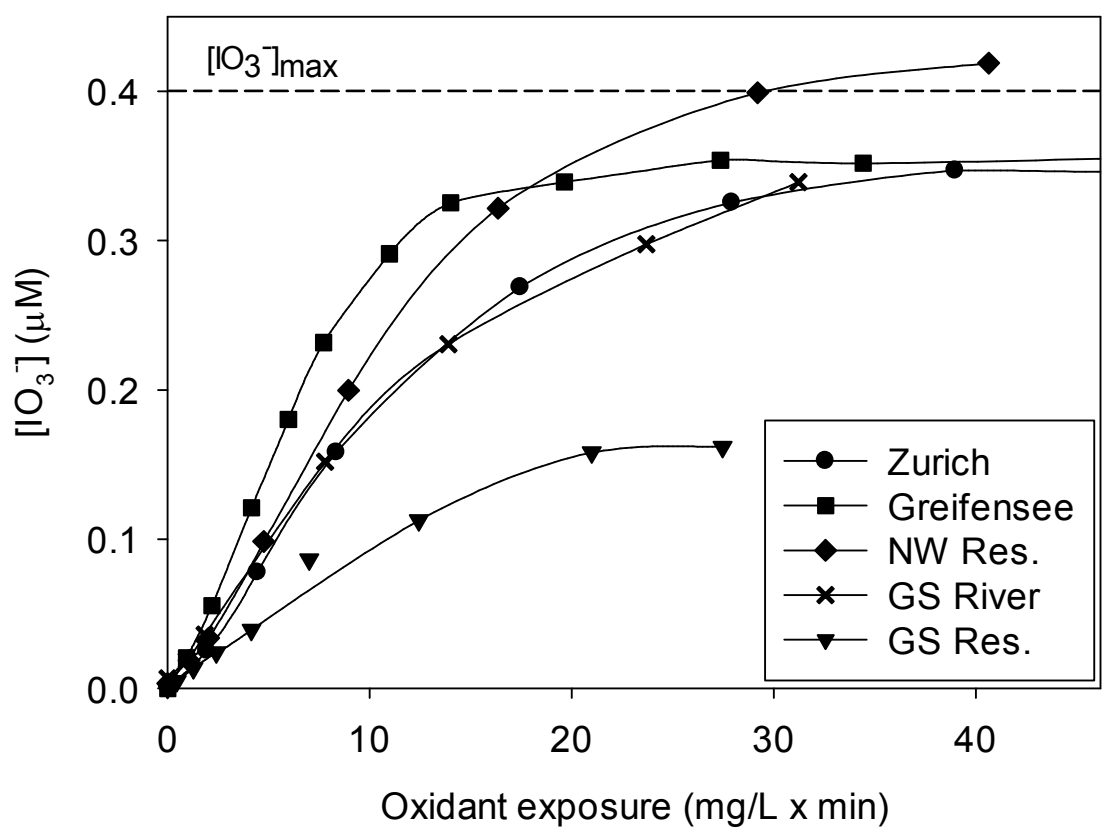

Figure 4. Kinetics of iodate formation for various natural waters (Table 1). Concentrations after dilution and spiking: $\left[\mathrm{I}^{\mathrm{I}}\right]_{0}=50 \pm 2 \mu \mathrm{g} / \mathrm{L}(0.4 \mu \mathrm{M}) ;\left[\mathrm{Br}^{-}\right]_{0}=105 \pm 5 \mu \mathrm{g} / \mathrm{L}(1.3 \mu \mathrm{M}) ; \mathrm{pH}=8.0 \pm 0.1$;

569 $\mathrm{DOC}=1.2 \pm 0.1 \mathrm{mg} \mathrm{C} / \mathrm{L} ;[\mathrm{HOCl}]_{0}=1-5 \mathrm{mg} \mathrm{Cl}_{2} / \mathrm{L}$. Lines are used to guide the eye.

570

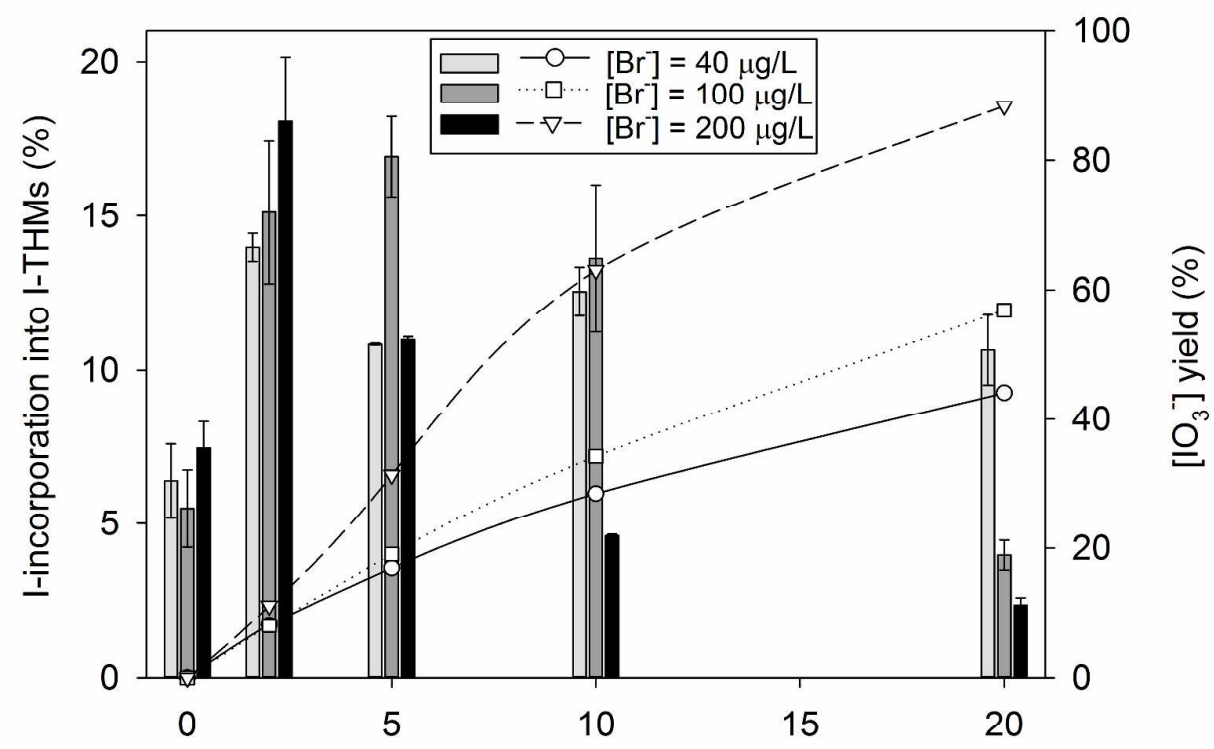

\section{1}

572

573

574

575

576

577

Prechlorination time (min)

Figure 5. lodine incorporation into I-THMs (bars) and iodate yield (lines) for various prechlorination contact times and varying bromide concentrations for Great Southern River water (concentrations after dilution and spiking: $\left[\mathrm{I}^{-}\right]_{0}=50 \mu \mathrm{g} / \mathrm{L} ;[\mathrm{Br}]_{0}=40,100$ and $200 \mu \mathrm{g} / \mathrm{L}$; $\mathrm{pH}$ 8.0; $\mathrm{DOC}=1.2 \mathrm{mg} \mathrm{C} / \mathrm{L})$. Chlorine dose: $1 \mathrm{mg} \mathrm{Cl} / \mathrm{L}(15 \mu \mathrm{M})$, ammonia addition: $75 \mu \mathrm{M} . \mathrm{t}=$ $0 \mathrm{~min}$, ammonia addition before the addition of chlorine. I-THMs were analysed after $24 \mathrm{~h}$ to simulate contact times in distribution systems. 


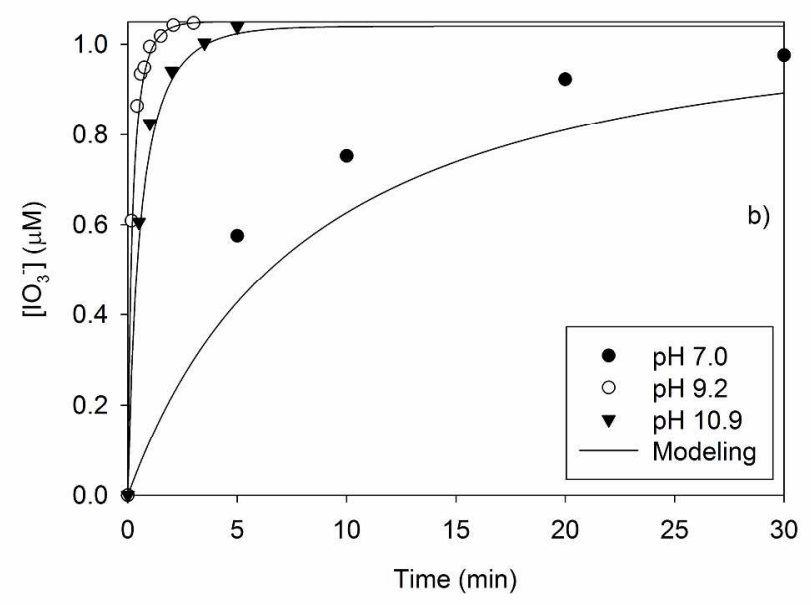

$296 \times 420 \mathrm{~mm}(300 \times 300$ DPI $)$ 


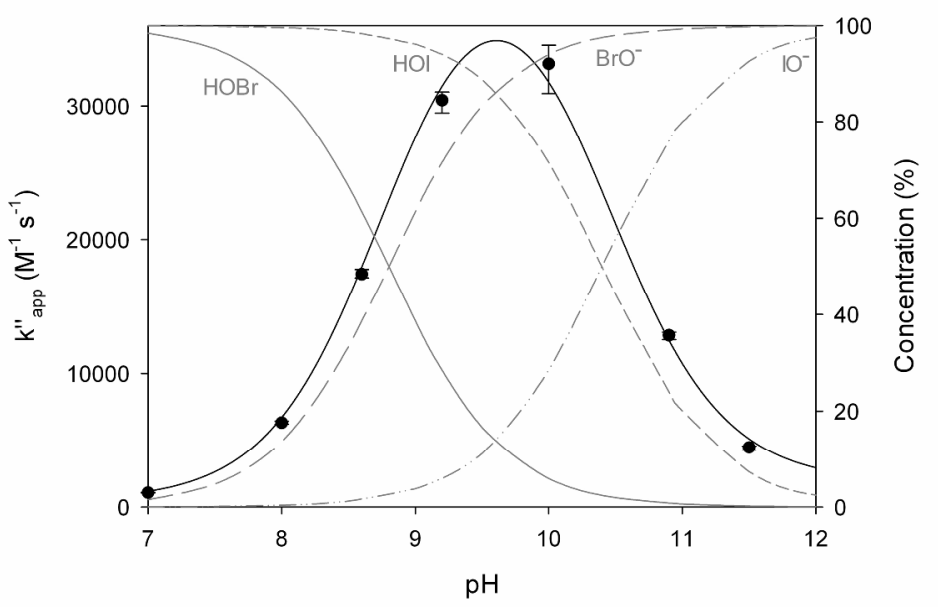

$320 \times 454 \mathrm{~mm}(300 \times 300$ DPI $)$

ACS Paragon Plus Environment 


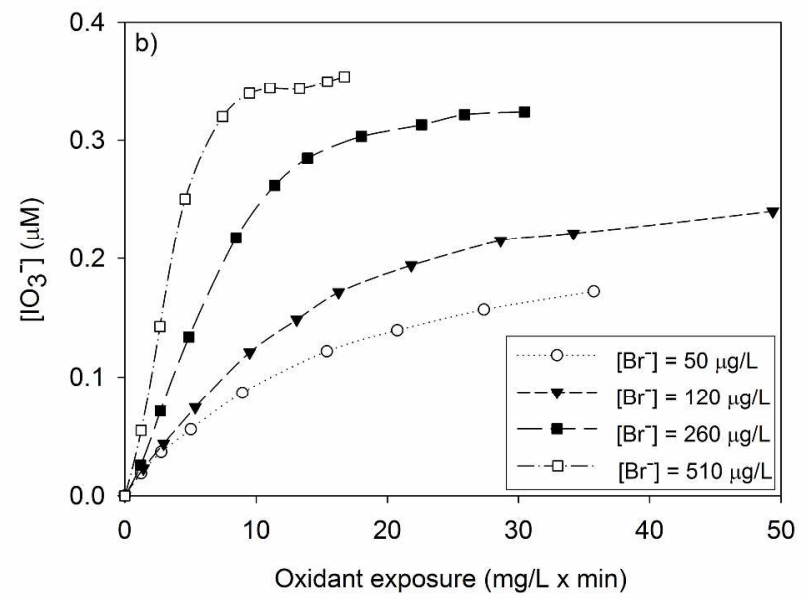

$296 \times 420 \mathrm{~mm}(300 \times 300$ DPI $)$ 


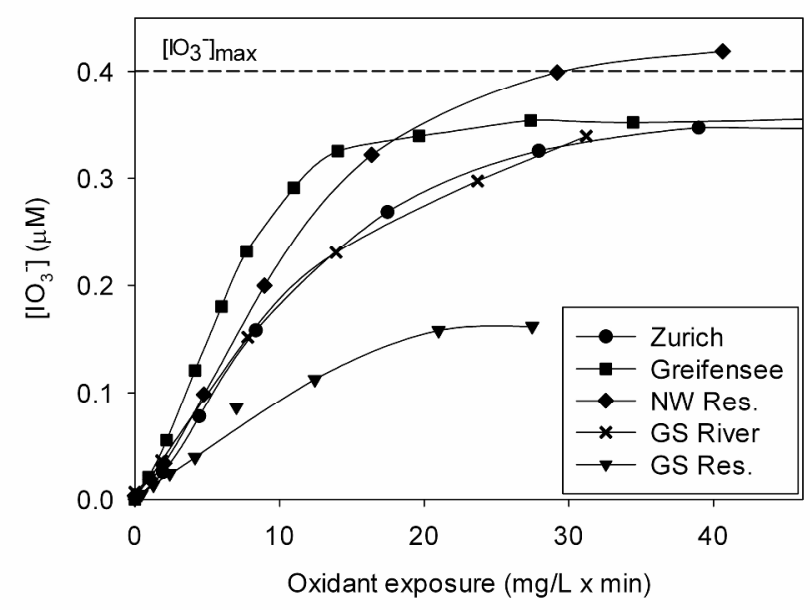

$320 \times 454 \mathrm{~mm}(300 \times 300$ DPI) 


1
2
3
4
5
6
7
8
9
10
11
12
13
14
15
16
17
18
19
20
21
22
23
24
25
26
27
28
29
30
31
32
33
34
35
36
37
38
39
40
41
42
43
44
45
46
47
48
49
50
51
52
53
54
55
56
57
58
60

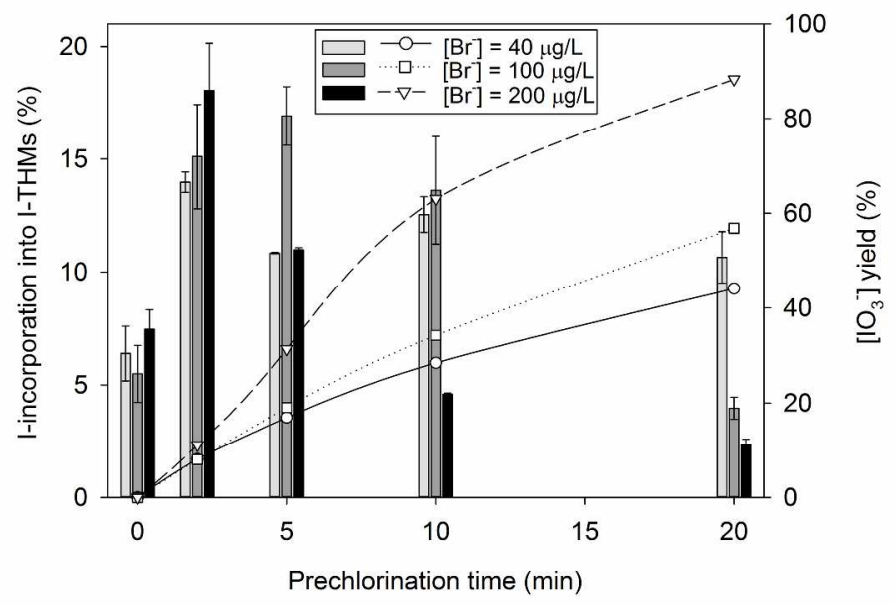

$296 \times 420 \mathrm{~mm}(300 \times 300 \mathrm{DPI})$ 